\title{
Problem Solving as a Mandatory Requirement for «Quality Management» Specialist
}

\author{
Olga G. Prelovskaya \\ Saint Petersburg Electrotechnical University "LETI" \\ St. Petersburg, Russia \\ ola.prelovskaya@gmail.com
}

\author{
Viktor P. Semenov \\ Saint Petersburg Electrotechnical University "LETI" \\ St. Petersburg, Russia \\ vps@etu.ru
}

\begin{abstract}
Problem solving as a part of Quality Management System (QMS) requires special attention for effective QMS operating. Proposed competitive company formula demonstrates important role of skilled company staff. Overview of "Quality Management» specialist requirements and functional responsibilities verifies required problem solving skills. Short summary of the main problem solving methods.
\end{abstract}

Keywords-problem solving; quality management; quality management system; improvement; specialist; skills; knowledge; methods; PDCA; 8D; DMAIC

\section{INTRODUCTION}

In recent years, major changes in company process management have been identified that is related with requirement to increase Russian products and service competitiveness.

Any company activity should be based on system and process management principles and basics, namely on quality management system as fundamental philosophy of company senior management as well as company operations in general, paying special attention to problem solving that requires timely changes in demanded skills and knowledge for qualified staff to sustain their competitiveness in labor market.

Manufactured products and provided services require robust problem solving, which is considered as fundamental background not only for company development but also for industrial and economic complex.

\section{QUALITY MANAGEMNT SYSTEM REQUIREMENTS}

Following is the list of ISO9000-2015 Quality Management System key principles:

- Customer focus;

- Leadership;

- People involvement;

- Process approach;

- Continual improvement;

- Factual approach to decision making;

- Mutually beneficial supplier relationships.
Mentioned above principles are based on continual improvement philosophy with important problem solving role in place. ISO9000-2015 terminology does not contain problem solving term, hence we introduce our interpretation:

Problem (Greek word "problema" - barrier, difficulty, task) - any deviation from expectation/requirement or any unwanted effect with unknown cause.

Consequently, applying to problem solving term we imply root cause searching and analysis, corrective and preventive actions implementation against identified and verified root cause (please refer to ISO9000-2015 for additional terms clarification, e.g. requirement, deviation and etc.)

There is one more item that should be emphasized related to ISO9000-2015 requirements - process approach deployment that include Do-Check-Act (PDCA), also known as Deming cycle. The core idea of this approach is based on continual improvement principles including problem solving algorithm that will be described below.

Thereby we may conclude that problem solving is integrated into key Quality Management System principles and require company special attention for effective QMS operating.

Considering company operations as a process that is a function of critical $\mathrm{X}$ factors we may refer to the following formula of competitive organization:

$$
\mathbf{Y}=\mathbf{f}(\mathbf{X})
$$

where:

$\mathrm{Y}$ - competitive organization

$\mathrm{X}$ - critical factors that impact company competitiveness

Completing formula with major critical factors that impact company competitiveness we obtain the following formula:

$Y($ competitive organization $)=$

$\mathrm{f}\left(\mathrm{X}_{1} /\right.$ Mission and values, $\mathrm{X}_{2} /$ Strategy, $\mathrm{X}_{3} /$ Structure, $\mathrm{X}_{4} /$ Fixed capital, $\mathrm{X}_{5} /$ Product or service, $\mathrm{X}_{6} /$ Qualified staff, $\mathrm{X}_{7} /$ Business processes, $\mathrm{X}_{8} / \mathrm{QMS}, \ldots \mathrm{X}_{\mathrm{n}}$ )

By means of cascading we focus on qualified staff that is required for effective operations:

$\mathrm{Y}$ (Qualified staff) = $\mathrm{f}\left(\mathrm{X}_{1} /\right.$ Management staff, $\mathrm{X}_{2} /$ Purchasing staff, $\mathrm{X}_{3} /$ Sales staff, $\mathrm{X}_{4} /$ Production staff, 
$\mathrm{X}_{5} /$ Quality management staff, $\mathrm{X}_{6} /$ Logistics staff, $\mathrm{X}_{7} / \mathrm{R} \& \mathrm{D}$ staff $\left.\ldots X_{n}\right)$.

There is no doubt that fundamental background of competitive company is based on qualified personnel, in particular staff engaged in quality management, that require mutually beneficial education and development by Universities as well as organizations.

Moving forward we shall focus on the major functional responsibilities and requirements, required knowledge and skills for «Quality Management» specialists.

\section{III. «QUALITY MANAGEMENT» SPECIALIST FUNCTIONAL RESPONSIBILITIES AND REQUIREMENTS}

In 2014 Ministry of Labour affirmed professional standard «Product quality management specialist» (Decree N 856n dated by 31.10 .2014 ), that describes professional activities in product quality management, highlighting the main goal of this kind of activity:

«Development, analysis, implementation and assistance in Quality Management Systems, related to organizations of all types of business and any forms of ownership, covering all organization processes, engaged into quality continual improvement and aimed to increase company competitiveness». There are highlighted 20 types of economic activities in this standard that also include Electrotechnical scope.

Major functional responsibilities and requirements related to problem solving are identified below:

1 General labour function: quality management activities in product manufacturing and service providing

1.1 Labour function: analysis of root causes effecting product (service) quality deterioration, development of action plans aimed to eliminate identified root causes:

1.1.1 Analysis of defects effecting attribute and quantitative indicators deterioration related to product (service) serial life

1.1.2 Root cause analysis of defects effecting attribute and quantitative indicators deterioration related to product (service) serial life

1.1.3 Corrective actions development to eliminate defects effecting attribute and quantitative indicators deterioration related to product (service) serial life

1.1.4 Analysis of implemented corrective actions related to defects that effected attribute and quantitative indicators deterioration related to product (service) serial life

1.1.5 Reporting to Management based on analysis results of implemented corrective actions aimed to eliminate defects that effected attribute and quantitative indicators deterioration related to product (service) serial life

\subsection{Required skills}

1.2.1 Skills: to apply actual regulatory documentation in product (service) quality management.
1.2.2 Skills: to apply methods of product (service) qualimetric analysis

\subsection{Required knowledge}

1.3.1 Knowledge: principle methods of product (service) qualimetric analysis in product manufacturing and service providing

1.3.2 Knowledge: quality management principle in product manufacturing and service providing

1.4 Other requirements: activities aimed to solve analytical tasks applying wide range of actual solving methods

Mentioned above examples are linked just to one general labour function that demonstrates skills and knowledge requirements in problem solving for «Quality Management». Specialists. It is necessary to emphasize that problem solving skills and knowledge are required for all general labour functions within discussed profession.

\section{MAIN PROBLEM SOLVING METHODS OVERVIEW}

\subsection{Deming PDCA Cycle}

First of all, we should highlight the common feature for the most known problem solving methods which is related to Deming PDCA Cycle, hence starting with its description.

Referring to Management literature PDCA cycle, also known as management cycle, is considered as continuously improving process that may be applied in any field of activity. The cycle consists of 4 steps or phases:

- P - Plan: problem identification (deviation from planned or desirable level); root cause analysis; potential problem solving steps; action plan to solve the problem.

- D-Do: planned actions implementation.

- C - Check: Control and monitoring of implemented actions effectiveness.

- A - Act: In case of identified deviations vs expected result there should be new PDCA cycle introduced.

Hereinafter we introduce problem solving methods classification based on root cause type:

1. Special causes related to unexpected changes that introduced negative effect. These type of problems are solved by means of $8 \mathrm{D}$ method (description will follow below).

2. Common causes are used to be in place for some period of time, not related to unexpected changes, but at some moment it was decided to eliminate them. Such kind of problems are solved by DMAIC method (description will follow below).

\subsection{D Problem solving method}

This method is aimed to identify, correct and prevent from reoccurrence of identified and similar problems enabling to improve product or service.

8D Problem solving methodology (8 Disciplines or steps) is a structured method that consists of 9 steps referring to numbered D steps (D0-D8), which are related to 9 Disciplines in total. 


\section{D Structure:}

D0: Preparation. Problem solving initiation to proceed to 8D. Planning and implementation of Emergency respond actions to protect the Customer against the symptom.

D1: Team identification. Team members identification.

D2: Problem description.

D3: Interim containment actions planning and implementation against problem symptom. Verification of implemented actions.

D4: Root cause and Escape point identification. Identification of one or several Root causes and Escape points that explain the problem the best way. Root cause(s) verification.

D5: Permanent corrective actions. One or several actions selection against identified and verified Root causes and Escape points. Verification of planned actions.

D6: Permanent corrective actions. Implementation of chosen actions and their validation.

D7: Preventive actions. Identification, selection and implementation of preventive actions.

D8: Team and Individual Recognition. Final step.

In recent years, 8D process has widely spread out of automotive industry. Its application range is not limited by problem solving only but also extended to Lean and Continuous improvement actions enabling its application for any processes.

\subsection{DMAIC Problem solving method}

This method is usually applied to existing process management and improvement, also known as 6Sigma philosophy. Special attention is paid to defect rate and process variability reduction using DMAIC method that consists of 5 steps or phases with first letter of each step in its name:

Define - this step implies Client and requirements identification, also product and process selection that requires improvement including metric for improvement.

Measure - within this step data about current status is collected, required or expected level is targeted, input and output variables are identified, measurement system should be validated.

Analyze - during this step the Team use data to identify key process input characteristics that impact on process outcome or result (filtering vital few characteristics from many trivial): most critical $\mathrm{X}$ factors identification, correlation analysis of Xs and investigated problem $\mathrm{Y}$ ): $\mathrm{Y}$ (investigated problem) $=\mathrm{f}$ (X/critical Xs) where result $\mathrm{Y}$ is a function of $\mathrm{Xs}$.

Improve - Improvement Action Plan is identified and implemented within this phase (Xs optimization in order to reduce defect rate or process variability). This step consists of critical Xs changes implementation identified in Analyze, enabling investigated problem (Y) be improved. Results verification and validation are also done during this phase.

Control - improved process documentation and monitoring, also confirmation of results sustainability.
Each problem solving method includes its specific tools that help to enhance problem solving process in an effective and efficient way.

Also it is reasonable to mention that each method requires its own format for completion that may be adopted by each company based on its needs and specifics.

Application of problem solving methods in Russia is on initial level reflecting Russian market specifics. This need is particularly urgent in electrotechnical companies that produce labor-intensive and sensitive products and services, validating special knowledge and skills requirement for specialists of this industry. Problem solving is considered as particular relevant discipline enabling to bridge professional market labor needs and highly skilled human resources education provided by Universities on Regional and Federal levels.

\section{CONCLUSION}

In order to summarize the following conclusions should be outlined:

1. Problem solving is actual and needed by most organizations with no reference to company field of activity.

2. Continuous improvement should be based on robust problem solving.

3. Company competitiveness significantly depends on qualified personnel.

4. «Quality Management» qualified staff should have knowledge and skills in problem solving.

5. Universities should be focused on required skills in order to meet market demand in qualified staff, in particular, knowledge and skills of problem solving methods and its specific tools.

\section{REFERENCES}

[1] Pavlyuk A.K., Merkusheva N.I. Analysis of 8D application in Russian companies. Molodoy ucheny. [Young scientist] 2015. No.1. P. 267-269. URL: https://moluch.ru/archive/81/14700/ (reference date: 06.10.2019). (In Russian)

[2] Semenov V.P. Theoretical aspects and problems of improving the quality of education. Sovremennoe obrazovanie: soderzhanie, tekhnologii, kachestvo. Materialy XXIV Mezhdunar. nauchnometodicheskoj konf. [Modern education: content, technology, quality. Materials of the XXIV International science and methodological conference], Saint Petersburg, April 18, 2018: in 2 volumes Vol. 1. SPb.: Publishing house of Saint-Petersburg Electrotechnical University "LETI", 2018. P. 31-33. (In Russian)

[3] Standard ISO9000-2015 Quality Management Systems. The main aspects and vocabulary. URL: https://standartgost.ru/g/ГОСТ_Р_ИСО_9000-2015 reference date: 06.10.2019). (In Russian)

[4] Standard ISO9001-2015 Quality Management Systems. Requirements. URL: http://docs.cntd.ru/document/1200124394 (reference date: 06.10.2019). (In Russian)

[5] Standard «Product quality managemnt specialist» (Ministry of Labour Decree N 856n dated by 31.10.2014). URL: https://sudact.ru/law/prikazmintruda-rossii-ot-31102014-n-856n/professionalnyi-standart (reference date: 06.10.2019). (In Russian)

[6] Gromov A.I., Bilinkis Y.A., Kazantsev N.S., Zueva A.G. Applying extended DMAIC methodology to optimize weakly structured business processes. Biznes-informatika [Business-informatics]. 2016. No.3 (37). P. 72-80. URL: https://elibrary.ru/item.asp?id=26690222 (reference date: 06.10.2019) (In Russian) 